\title{
JUURNAL.RU
}

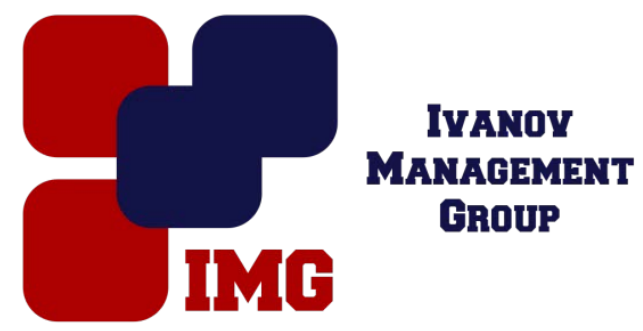

Калюжный А.О. СГТУ им. Ю.А. Гагарина Саратов, Россия

doi: 10.18411/lj-25-12-2016-1-09

idsp 000001:lj-25-12-2016-1-09

\section{Модернизация конструкции имплантата грудной клетки}

\author{
Научный руководитель: Пичхидзе С.Я.
}

\section{Аннотация}

В статье рассматривается вопрос усовершенствования конструкции имплантата грудной клетки с использованием хондроитина.

Ключевые слова: имплантат грудной клетки, хондроитин, ребро.

Такое распространенное повреждение, как перелом ребер достигает около $16 \%$ от общего количества переломов. Неосложненные переломы обычно одного или двух ребер не представляют большой угрозы, поскольку быстро и без труда срастаются. Зачастую перелом грудной клетки сопровождается сильным повреждением легких, плевры и органов сердечно-сосудистой системы. Основной причиной перелома ребер обычно бывает прямой удар в центр области грудной клетки, падение или сдавливание ребер человека. В месте наиболее сильного изгиба ребра ломаются по боковым поверхностям грудины. При множественных переломах смещение отломков практически неизбежно. Своими острыми концами ребра могут повредить плевру, межреберные сосуды и легкие. Бывают ситуации, когда необходимо использовать имплантат грудной клетки [1, 2].

Цель работы: усовершенствование конструкции имплантата грудной клетки с использованием хондроитина.

Хондроитин - высокомолекулярный полисахарид, относящийся к группе гликозаминогликанов. Вырабатывается хрящевой тканью суставов, входит в состав синовиальной жидкости. Необходимым строительным компонентом хондроитина является глюкозамин; при недостатке глюкозамина в составе синовиальной жидкости образуется недостаток хондроитина, что ухудшает качество синовиальной жидкости и может вызвать хруст в суставах. Стимулирует синтез гиалуроновой кислоты, укрепляя соединительнотканные 
структуры: хряща, сухожилий, связок, кожи. Оказывает анальгетическое и противовоспалительное действие, является хондропротектором, способствует активной регенерации хряща [3].

Поверхность кости следует обработать 7\% водным раствором сульфата гликозаминогликана (хондроитин сульфата) с добавлением в него $2 . . .4 \%$ цинкгидроксиапатита для придания покрытию антимикробного эффекта.

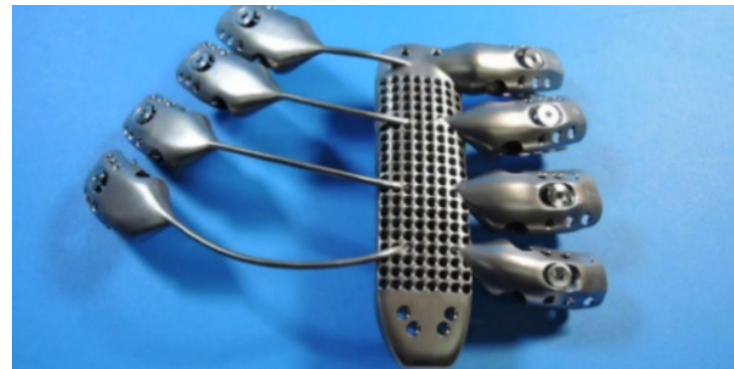

Рис.1. Имплантат грудной клетки из титанового сплава

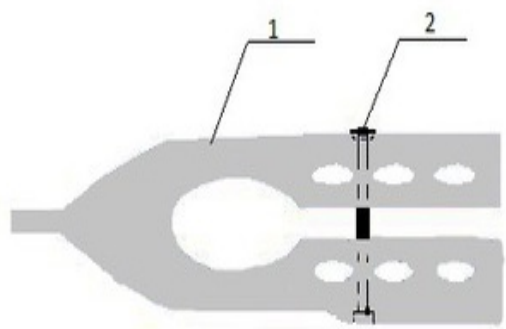

Рис.2.Место контакта имплантата с костью, где: 1- часть имплантата, 2 - крепёжный болт, 3 - хондроитин,4 - ребро

Выводы: показано, что использование хондроитина для обработки кости на месте контакта с имплантатом улучшит связь между костью и имплантатом и ускорит рост хряща.

\section{Литература}

1. Романенко А.Е, Чухриенко Д.П., Мильков Б.О. Закрытые повреждения органов грудной клетки. Киев: Здоров'я, 1985. - 160с.

2. Махамбетчин М.М. - Закрытая травма грудной клетки. Проблемы диагностики, Логосфера, 2016. - 232c.

3. http://enures.dacha-dom.ru/chondroitin.shtml

4. Патент РФ №2510250.Устройство для применения при хирургическом лечении воронкообразной деформации грудной клетки и способ лечения/ Бардахи Паскуаль Карлос, заявл. 2009-08-17, опубл. 27.03.2014.

5. Патент РФ № 2166292. Способ лечения килевидной деформации грудной клетки детей / Стальмахович В.Н. ДюковА.А., Найманова А.П., заявл. 2008-12-29, опубл. 20.04.2010. 